\title{
THE EXPERIENCE, TASK VALUE AND SELF-EFFICACY OF NURSING STUDENTS IN ATTENDING BLENDED LEARNING IN BASICS SCIENCE IN NURSING 2 COURSE IN FACULTY OF NURSING UNIVERSITAS PADJADJARAN
}

\author{
Authors: \\ Ryan Hara Permana ${ }^{1 *}$, Dian Adiningsih ${ }^{2}$ \\ ${ }^{1,2}$ Nursing Faculty, Universitas Padjadjaran \\ Email* : ryan.hara@unpad.ac.id
}

\begin{abstract}
Introduction: The implementation of blended learning in nursing education is needed to provide quality and efficient learning. There is a need for an investigation of students' experience in following blended learning especially in the subject of basic science in nursing 2 including anatomy, physiology, biochemistry, pathophysiology and pharmacology in nursing topics. This study aims to provide an ideal picture for students of the Faculty of Medicine in Indonesia. Methods: This study occupied quantitative descriptive research method with simple random sampling technique. The respondents were 93-second years students of the Faculty of Nursing, UniversitasPadjadjaran. The Learning Experience Questionnaire (LEQ) instrument was used to measure students' experience. The data were analysed using percentage analysis. Results: More than a half of total respondents had good experience in participating in mixed learning of IDK course. Conclusions: Students'good experience may be influenced by the availability of student access to the internet, and the instructional design of the blended learning. The main obstacle in implementing the course were a large learning credit burden and extensive coverage of the learning material. Technology skills training and habituation of blended learning needs to be given by the faculty before students take part in blended learning.
\end{abstract}

Keywords: blended learning; learning experience; nursing education

\section{INTRODUCTION}

Blended learning is one of the online learning methods that has the ability to promote and assist faculty adaptation, both lecturers and students, to transform from conventional to online learning (Bonk \& Graham, 2012; Garrison \& Vaughan, 2008). Blended learning is a combination of traditional didactic learning and the use of digital technology that helps students learn more productively. Blended learning provides a space for lecturers and students to take advantage of digital technology that they master in maximizing teaching and learning. But they still have the opportunity to carry out traditional teaching and learning activities (Bonk \& Graham, 2012). Chaeruman (2017)explains that blended learning is a form of learning system that mixes synchronous and asynchronous learning strategies to produce learning experiences to help students achieve the targeted learning outcomes. Blended learning places online learning as a unified whole in its integration with face-to-face learning in a curriculum or lesson plan.

The application of blended learning in nursing education is considered to have good effectiveness in increasing critical thinking and learning satisfaction (Jang \& Hong, 2016). Many literatures state that blended learning is useful in increasing cognitive outcomes, learning effectiveness, and decreasing dropout rates (Hsu, 2011; Jang \& Hong, 2016; Wu, Chan, Tan, \& Wang, 2018). McCutcheon, Lohan, Traynor, and Martin, (2014)explained that blended learning compared to traditional learning, was relatively comparable in its effectiveness in improving clinical skills of nursing students. In addition, blended learning also supports interactions between lecturers and students in nursing education as it promotes active learning especially in analyzing cases and solving problems (Hsu, 2011).

The implementation of blended learning in nursing education in Indonesia is currently emerge. This due to the support from the Ministry of Research, Technology and 
Higher Education with a program called Sistem Pembelajaran Daring (SPADA) Indonesia (Kemenristekdikti, 2016) aiming to improve online learning implementation in higher education. However, the study on the use of blended learning in nursing education is still limited. The earlier study by to investigate the experience of the nursing students in the Faculty of Nursing, Unpadin participating in blended learning of Basics Science of Nursing 2 course.

\section{METHODS}

Table 1. Distribution of Frequency of Demographic Characteristics of Respondents

\begin{tabular}{ccc}
\hline Characteristics & Frequency & Percentage (\%) \\
Sex & 8 & 8.6 \\
Male & 85 & 91.4 \\
Female & & \\
Have internet access & 93 & 100 \\
Yes & 0 & 0 \\
No & 0 & \\
\hline
\end{tabular}

Table 2. Distribution of Frequency ofStudent Experience

\begin{tabular}{|c|c|c|c|c|c|c|c|c|}
\hline \multirow[t]{2}{*}{ Variables } & \multicolumn{2}{|c|}{ Good } & \multicolumn{2}{|c|}{ Bad } & \multirow{2}{*}{$\begin{array}{c}\text { Min. } \\
2.36\end{array}$} & \multirow{2}{*}{$\begin{array}{l}\text { Max. } \\
6.32\end{array}$} & \multirow{2}{*}{$\begin{array}{c}\text { Median } \\
4.59\end{array}$} & \multirow{2}{*}{\begin{tabular}{|l} 
Mean \\
4.59
\end{tabular}} \\
\hline & $\mathrm{f}$ & $\%$ & $\mathrm{f}$ & $\%$ & & & & \\
\hline & 48 & 52 & 45 & 48 & & & & \\
\hline
\end{tabular}

Sumartiningsih, (2015) evaluated the effectiveness of blended learning model in a nursing school in Indonesia. In addition, Permana, Ardiansah, and Adiningsih (2017) specifically investigated the use of Learning Management System (LMS) on blended learning in nursing education.

One of the indicatorsof good blended learning is the students'good learning experiences. Students' good experience will determine their self-efficacy in following the next blended learning sustainably (Taipjutorus, 2015). However, a bad experience might reduce students' self efficacy. Students' learning experience is influenced by learning environments, learning support, teaching characteristics, learning challenges and personal factors (George, Lakra, \& Kamath, 2017). Instructional design provides good learning experience for students as it helps students to follow the learning activities, engage in the learning process and gained a satisfyingmark. The purpose of this study was
This research is a quantitative descriptive study. The population in this study were 93 undergraduate nursing students of 2017 of Universitas Padjadjaran who volunteered to take part in this study. The sampling technique uses simple random sampling. The blended learning model in Basic Sciences of Nursing 2 course used flipped classroom strategy, the instructional strategy that reverses learning activities that occur inside and outside the classroom (Baepler, Walker, \& Driessen, 2014). The submission of lecture materials that is usually delivered in the classroom, is changed to be delivered outside the class before face-to-face sessions. The submission of the materials is facilitated by a Learning Management System (LMS) so that students are able to access material wherever. While the practice of questions and tasks that are usually done outside the classroom, is changed to be implemented in the classroom. Flipped classroom strategy was conducted so that the 
face-to-face activities can be occupied to help students achieve higher learning outcomes, for example being able to solve problems in a case.

The implementation of blended learning in the Faculty of Nursing, Universitas Padjadjaran (Unpad) has a great potential supported by adequate learning facilities. Historically, the Faculty of Nursing Unpad have been using blended learning since 2003, held online class with Kuwait in 2008 and using LiVEUnpad, a Moodle-based LMS, since 2010. Basic Nursing Science 2 course (IDK2) applied blended learning with a range of topics namely anatomy, physiology, biochemistry, pathophysiology and pharmacology in nursing with a weight of 6 credits. Thus, the competencies in this course fundamentally supports clinical nursing skills.

Blended learning model in the Basics Science in Nursing 2 course consists of a combination of face-to-face and online learning. The material is distributed by online a week before the face to face sessions. The learning materials consist of videos, PDF and PPT files, e-book, and website links. The online quiz serves as formative evaluations as well as stimulation for students to access material before face to face sessions. The online assignment announced before face to face sessions to provide a space for students to analysis material or challenges their concept in clinical cases. The face to face or lecture session, focusing on the discussion of assignments that have been given and to review the materials. The online discussion forum is an activity for students to conduct online discussions a synchronously about the analysis and follow-up questions from the assignment given.

\begin{tabular}{|c|c|}
\hline Online & Face-to-face \\
\hline Materials & \\
(pdf, ppt, e-book) & \\
Quiz & \\
Assignment & \\
\hline
\end{tabular}

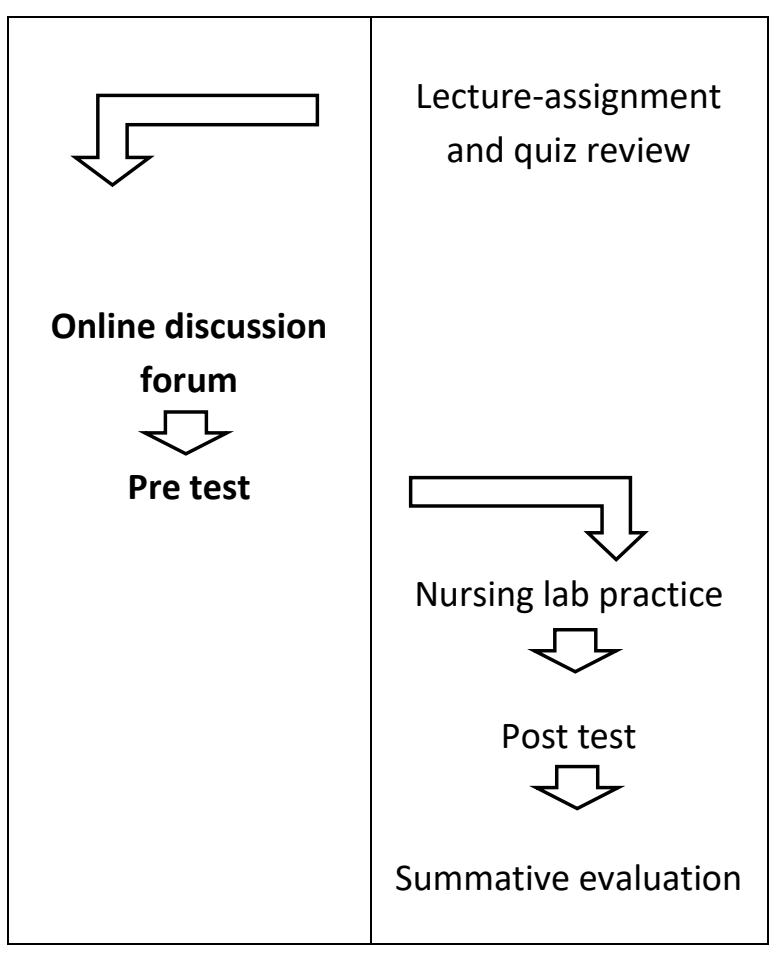

Diagram 1. Model Blended Learning IDK 2

Student learning experience was measured by the Learning Experience Questionnaire (LEQ) questionnaire which contains 22 closed statements. The LEQ instrument aims to capture the picture of student learning experiences after following a blended learning course. The LEQ instrument a questionnaire consists of 22 statement items, measured using a Likert scale ranged from one to seven score. The scale interpretation is $1=$ "strongly disagree", up to 7 = "strongly agree" (Borglund et al., 2016). The total LEQ value that is higher than the median indicates that the experience is considered good, whereas if the total LEQ value is lower than the median then the experience is considered to be bad.

Data analysis was done by enumerating the value of item statement number 1-22 from the LEQ questionnaire (Borglund et al., 2016). The maximum value for the experience variable is 154 and the minimum value is 22 . The higher the total value of experience, the better the level of student experience. Respondents' participation in this study were voluntary and provided with an informed consent listed in the online questionnaire. The respondents were not vulnerable groups and there were no invasive actions. Research was carried out at the appropriate time and did not interfere with the learning process. In addition, the 
confidentiality of data is guaranteed by anonymous principles and limited access to the data with only the research team has access.

\section{RESULTS}

Based on Table 1, the demographic characteristics of the data obtained were 85 female students $(91.4 \%)$ and all respondents who had internet access (100\%).

Based on Table 2, $52 \%$ of respondents had good experience in participating in blended learning in the Basic Nursing Science course. Item statement number 1, namely "I learn interesting things in this course" has the highest average of 5.21. In addition, item number 12, namely "Activities in this course help me achieve the learning achievement that I expected efficiently" has the lowest average of 4.05 .

\section{DISCUSSIONS}

All respondents in this study had internet access. This is in accordance with data from the Indonesian Internet Service Providers Association in 2017 (APJII, 2017), the number of internet users in Indonesia is quite high, reaching $34.9 \%$ of the total population of Indonesia or 88.1 million people.

The experience in this study is interpreted as the views of students during the blended learning process in the Basics Science in Nursing 2 course. That is, during the course of the blended learning activities from the beginning to the end, students will get a view of blended learning wether good or bad views. Learning experience is a process that has been passed and obtained by the five senses such as the process of imitating, self regulated activity, and following the direction given (Vardiansyah, 2008).

More than a half of the nursing students (52\%) had good experience in participating the blended learning. Research on learning experiences in post graduate nursing students in Ireland by Smyth, Houghton, Cooney, and Casey (2012) shows that students have positive experiences in following blended learning. Positive experiences of students in following blended learning are also reported by Shorey, Siew, and Ang, (2018) where students feel that blended learning increases learning outcomes and their confidence in dealing with problems especially related to interprofessional communication.

A good experience score might be influenced by students' adequate access to the internet (100\%). A research by Alzahrani and O'Toole, (2017) shows that student experience in following blended learning is influenced by the behavior of internet usage. Respondents who have longer experience in using the internet for learning have a better experience in following blended learning compared to respondents who have a shorter experience in using the internet to study. In addition, technological skills, especially computer use, also affect student experience. Therefore, students need to be given a computer skills training as a preparation before participating in blended learning.

The blended learning model in this study may also influence students' learning experiences. Rigby et al., (2012) states that combining group of face to face sessions with online learning is the most acceptable and effective blended learning model that meets the needs of students who have diverse learning styles. Students become more aware of the importance of clinical supervision and their role as supervisees. The use of social media needs to be added to the existing learning model because it can have a positive impact. Ferguson et al., (2017) recommends the use of social media for learning in blended learning in nursing education. Integration between social media and face-to-face increases student attention, engagement with learning activities, and average student satisfaction in following blended learning.

The respondents reported that efficiency in the learning process to achieve learning outcomes in this course was considered good. A lot of literature states that blended learning is a learning method that is able to improve learning outcomes, critical thinking skills, attitudes, and student selfconfidence(Milic et al., 2018; Mosalanejad, Alipour, Zare, \& Koolaee, 2012). Baragash and Al-Samarraie (2018) states that the combination of online learning and face-toface improves student learning performance. Students' engagement in face-to-face sessions has a positive impact on student involvement in online learning. In addition, the use of technology in blended learning is also capable to facilitate distance learning at an affordable 
and relatively efficient cost(Lothridge, Fox, \& Fynan, 2013).

Item statement number 18 which is "I regularly spend time reflecting on what I have learned in the Basics Science of Nursing 2 course" has a mean of 4.29 or in the good category. This indicates that respondents regularly review the learning material so that blended learning provides a good experience for respondents, especially in stimulating students to reflect on their learning outcomes. This is supported by a study by Norbye and Furu, (2010) regarding the contribution of blended learning to reflection practices on nurses, physiotherapists and occupational therapists in geriatric rehabilitation services. Norbye and Furu, (2010) explain that health workers reflect on reflection activities when they have time. Blended learning is considered to contribute to a flexible reflective learning structure that supports the sustainability of competency development in the health profession.

The respondent's positive experience toward this blended learning may also be influenced by respondents' interest on the learning materials. The average score in statement number 1 indicates that the learning material in this course is considered interesting by the respondents. This may be influenced by the content of the course which was a new knowledge for the students. Basic Science in Nursing 2 materials cover the science of human anatomy and physiology, biochemistry and physics and their implications for nursing. However, the results of the study show that the percentage of poor student learning experiences is quite large at $48 \%$. The factors that might influenced this were the ability of students to use LMS. Hubackova and Semradova (2016) explain that the success of students in participating in blended learning depends not only on the quality of pedagogical design and learning environment but also on the level of preparation of students, especially the ability to master technology.

The percentage of students' bad experience was still relatively high at $48 \%$. This is due to the obstacles reported by the respondents. The obstacles in implementing this blended course were the relatively large credit burden of the subject and the broad range of its materials. The total credit in this course were six credit points. In addition, the scope of learning materials included the science of anatomy, physiology, biochemistry, pathophysiology and pharmacology in nursing. The higher number of sample size is required to gain a more robust result. A wider population might also increase the insights about blended learning in nursing education. A multi-years cohort study could be applied to evaluate the impact of blended learning.

\section{CONCLUSIONS}

More than a half of the respondents have good experience in participating the blended learning mode in Basics Science of Nursing 2 course. This may be influenced by the availability of students' access to the internet. Another factor that might be influential is the design of blended learning in this basic course. This blended course is also considered efficient in facilitating learning. The flexibility of blended learning supports the students in accessing materials and learning interactions. The respondents also have motivation, interest and good behavior towards the application of blended learning so that the active learning process can be carried out including regularly reviewing learning material. The obstacles to the implementation of blended learning are mainly the large credit burden and the broad scope of learning materials. Computer skills training needs to be given to students as a preparation before participating in blended learning. A more rigorous research needs to be conducted by including other factors that influence the success of blended learning implementation such as attitudes, perceptions, policies and culture of teaching and learning environment.

\section{REFERENCES}

Alzahrani, M. G., \& O’Toole, J. M. (2017). The Impact of Internet Experience and Attitude on Student Preference for Blended Learning. Journal of Curriculum and Teaching, 6(1), 65. https://doi.org/10.5430/jct.v6n1p65

APJII. (2017). Infografis Penetrasi dan Perilaku Pengguna Internet Indonesia 2016 APJII.

Baepler, P., Walker, J. D., \& Driessen, M. (2014). It's not about seat time: Blending, flipping, and efficiency in active learning classrooms. Computers \& Education, 78, 227-236. 
Baragash, R. S., \& Al-Samarraie, H. (2018). Blended learning: Investigating the influence of engagement in multiple learning delivery modes on students' performance. Telematics \& Informatics, 35(7), 2082-2098. Retrieved from http://10.0.3.248/j.tele.2018.07.010

Bonk, C. J., \& Graham, C. R. (2012). The handbook of blended learning: Global perspectives, local designs. John Wiley \& Sons.

Borglund, D., Carlsson, U., Tosti, Massimiliano, C., Havtum, H., Hjelm, N., ․ KTH. (2016). Learning Experience Questionnaire: Course Analysis for Development, Version 2 ECE Teaching and Learning in Higher Education No 2. Stockholm: KTH Vetenskap Och Konst.

Chaeruman, U. A. (2017). PEDATI, Model Desain Sistem Pembelajaran Blended. Direktorat Pembelajaran Kementrian Riset, Teknologi Dan Pendidikan Tinggi.

Garrison, D. R., \& Vaughan, N. D. (2008). Blended learning in higher education: Framework, principles, and guidelines. John Wiley \& Sons.

George, L. S., Lakra, A. J., \& Kamath, A. (2017). Factors affecting learning among undergraduate nursing students: Crosssectional survey. Journal of Clinical and Diagnostic Research, 11(11), JC01-JC04.

Hsu, L.-L. (2011). Blended learning in ethics education: A survey of nursing students. Nursing Ethics, 18(3), 418-430.

Jang, H. J., \& Hong, S. Y. (2016). Effect of blended learning in nursing education. International Journal of Multimedia and Ubiquitous Engineering, 11(5), 297-304.

Lothridge, K., Fox, J., \& Fynan, E. (2013). Blended learning: efficient, timely and cost effective. Australian Journal of Forensic Sciences, 45(4), 407-416. Retrieved from http://10.0.4.56/00450618.2013.767375

McCutcheon, K., Lohan, M., Traynor, M., \& Martin, D. (2014). A systematic review evaluating the impact of online or blended learning vs . face-to-face learning of clinical skills in undergraduate nurse education. https://doi.org/10.1111/jan.12509

Milic, N., Masic, S., Bjegovic-Mikanovic, V., Trajkovic, G., Marinkovic, J., MilinLazovic, J., ... Stanisavljevic, D. (2018).
Blended learning is an effective strategy for acquiring competence in public health biostatistics. International Journal of Public Health, 63(3), 421-428. https://doi.org/10.1007/s00038-0171039-5

Mosalanejad, L., Alipour, A., Zare, H., \& Koolaee, A. K. (2012). A Blended Educational Program: Impact of Cognitive and Metacognitive Learning on Undergraduate Students. Middle East Journal of Nursing, 6(3), 12-17. Retrieved from http://search.ebscohost.com/login.aspx?d irect $=$ true $\& d b=r z h \& A N=111793355 \&$ sit e=ehost-live

Permana, R. H., Ardiansah, I., \& Adiningsih, D. (2017). Blended Learning Platform Development in Faculty of Nursing, Universitas Padjadjaran. In International Conference on Disaster Management \& Infection Control (Vol. 1, p. 81).

Rigby, L., Wilson, I., Baker, J., Walton, T., Price, O., Dunne, K., \& Keeley, P. (2012). The development and evaluation of a 'blended' enquiry based learning model for mental health nursing students: "making your experience count". Nurse Education Today, 32(3), 303-308. https://doi.org/10.1016/j.nedt.2011.02.00 9

Shorey, S., Siew, A. L., \& Ang, E. (2018). Experiences of nursing undergraduates on a redesigned blended communication module: A descriptive qualitative study. Nurse Education Today, 61, 77-82. https://doi.org/10.1016/j.nedt.2017.11.01 2

Smyth, S., Houghton, C., Cooney, A., \& Casey, D. (2012). Students' experiences of blended learning across a range of postgraduate programmes. Nurse Education Today, 32(4), 464-468. https://doi.org/10.1016/j.nedt.2011.05.01 4

Sumartiningsih, S. (2015). Correlation Between Blended Learning Model With The Perspective Of Learning Effectiveness For Nursing Student. International Journal of Scientific \& Technology Research, 4(6), 360-363.

Taipjutorus, W. (2015). The relationship between learner control and online learning self-efficacy.

Vardiansyah, D. (2008). Filsafat Ilmu 
Jurnal INJEC Vol. 3 No. 2 December 2018: 94-100

Komunikasi: Suatu Pengantar. Jakarta: Indeks.

Wu, X. V., Chan, Y. S., Tan, K. H. S., \& Wang, W. (2018). A systematic review of online learning programs for nurse preceptors. Nurse Education Today, 60, 11-22. 